\title{
Dr. Hassan Hathout, A Man of God
}

$I^{\prime}$ $t$ is my pleasure to write a profile on Dr. Hassan Hathout, a great American Muslim, a distinguished physician, ethicist, man of letters, prolific writer, great orator, and an Islamic leader. I have known him since we were both medical students, almost 60 years ago. He joined the School of Medicine, Ain Shams University at its inception in the early 1940s and graduated in December 1947.

Throughout his life, Dr. Hathout showed his love for humanity. When he was a student he used to celebrate Christmas by arranging social activities on campus in which both Muslims and Christians gathered together to celebrate the birthday of Jesus. In 1948, during the Arab-Israeli war, he was stationed as a young physician in the city of Ramleh in Palestine. When the Israelis captured it, he was outside the city. When he asked them to deliver an Egyptian colleague, the Israelis agreed to his request, and, in addition, sent back to him his operating room equipment with which he was working in Ramleh, declaring that it was a gesture of their gratitude for the humane treatment he accorded wounded Jewish captives brought to his care.

Dr. Hathout, the physician, specialized in obstetrics and gynecology and received his extensive postgraduate training in Britain at the University of Edinburgh, Scotland. There, he earned the triple degrees of Fellow of the Royal College of Surgeons (FRCSE), Fellow of the Royal College of Obstetricians and Gynecologists (FRCOG), and doctorate of philosophy (PhD) in the field of reproductive genetics. Subsequent affiliations included Fellowship of the American College of Surgeons (FACS), International Federation of Obstetricians and Gynecologists (FIGO), and the World Health Organization (WHO) committee for medical ethics. He was professor of obstetrics and gynecology at the University of Asyut, Egypt, member of the planning committee of the Medical School at the University of Kuwait, founding professor of obstetrics and gynecology at that

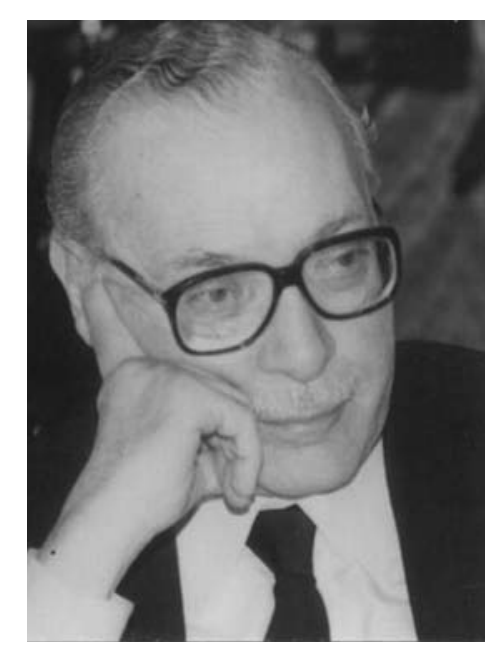

Dr. Hassan Hathout school, and professor of history of medicine and medical ethics, Kuwait University 1973-1988.

Dr. Hathout has written more than 100 papers in his specialty, which were published in relevant journals in the United States, Britain, and the Arab world. He authored several books on medical issues, including

the following:

- Gynaecology and Maternal Care, a nursing school teaching textbook for the Ministry of Public Health in Kuwait.

- Islamic Perspectives in Obstetrics \& Gynaecology, ${ }^{1}$ an invaluable resource for Muslim physicians and physicians handling Muslim patients.

Dr. Hathout was a key founder of the Islamic Organization of Medical Sciences (IOMS), headquartered in Kuwait. Its primary goal is the dissemination of God-guided, value-based medical ethics in rapidly advancing controversial fields such as reproductive medicine, assisted reproductive technology, alternative medicine, genetic engineering, organ transplantation, and stem-cell research. He attended almost all of its annual meetings and was an active participant in formulating its recommendations and policies. He authored books ${ }^{2,3}$ under the auspices of IOMS and participated in writing some of its position papers. 4

Dr. Hathout is a well-accomplished, well-recognized man of letters in Arab countries. He is one of the few people who can speak classical Arabic with- 


\section{Selected Awards}

1979: Recognition of the Arab Board for Medical Specializations, Specialty of Obstetrics and Gynecology 1999 and 2001: Certificates of special recognition from the Congress of the United States

2001: Olive Branch Award from the American Friends Service Committee, Los Angeles, California

2004: Outstanding Achievement Award from the Egyptian American Organization, Palos Verdes Peninsula,

California

2005: Life Changing Award from the Initiatives of Change International Organization, Caux, Switzerland

2006: Certificate of recognition from the Islamic Society of North America

2007: Recognition of Scholarly Mentorship of the Los Angeles Latino Muslim Community

2007: Certificate of recognition in community leadership, California State Assembly

out grammatical mistakes. His mastery of the Arabic language is widely appreciated. His dīwān (poetry collection) Jirāh wa afrāh (Wounds and Pleasures) 5 gained him recognition as a first-class poet in the Arab world. Among his beautiful poems are "The Migration," "In the Hands of the Prophet," and "Jesus, the Son of Man."

He contributed innumerable writings, broadcasts, and television appearances in the Arab media dealing with religion, science, and society that have always been tremendously appreciated (see box).

Dr. Hathout's book Bi hādhā alqā Allāh (Mu'assasa Fahd al-Marzūq al-Ṣuhufīya lil-țibā'a wa al-nashr: Kuwait; 1998) was a stunning success and generated a significant amount of money, all of which he donated to the education fund of the Islamic Center of Southern California in Los Angeles. It has also been translated into English. His book Reading the Muslim Mind (American Trust Publications; 1995) was, and still is, a successful display of true Islam to its readers, both Muslim and non-Muslim.

His latest book, Audible Silence: Thoughts and Remembrances of a Muslim Elder ${ }^{6}$ is a masterpiece of one-page stories, each giving rich "food-forthought" on the ideal human behavior. He shows how to introduce Divine values to a readership that is not particularly interested in religion. It also brings to mind that there are different and differing human beings, but that there are common universal human values. A second edition is now being published in both Arabic and English.

The relationship with God has always been the axial point of Dr. Hathout's life. He believes that such a relation emanates from the depth of the heart and is manifested by behavior through the journey of life. He believes that the essence of religion is basically love; rules and regulations come next.

Dr. Hathout is widely known in the religious community in the United States. He is a khatiib (preacher) in Friday prayers and frequently preaches the message of love, mercy, and justice in Islam.

He was the keynote speaker at the first ChristianMuslim celebration at the White House in 1999. Additionally, he is the cofounder of the Interfaith Council of Southern California and is involved in interfaith activities throughout the United States. He is the recipient of many awards (see box) from interfaith and humanitarian communities, including the Jewish-Christian-Muslim Olive Branch award for his efforts in making peace and harmony between people of different faiths.

Dr. Hathout resides in Pasadena, California, with his wife of 56 years, Salonas, a retired pathologist. His daughter, Eba, is professor of pediatrics at the

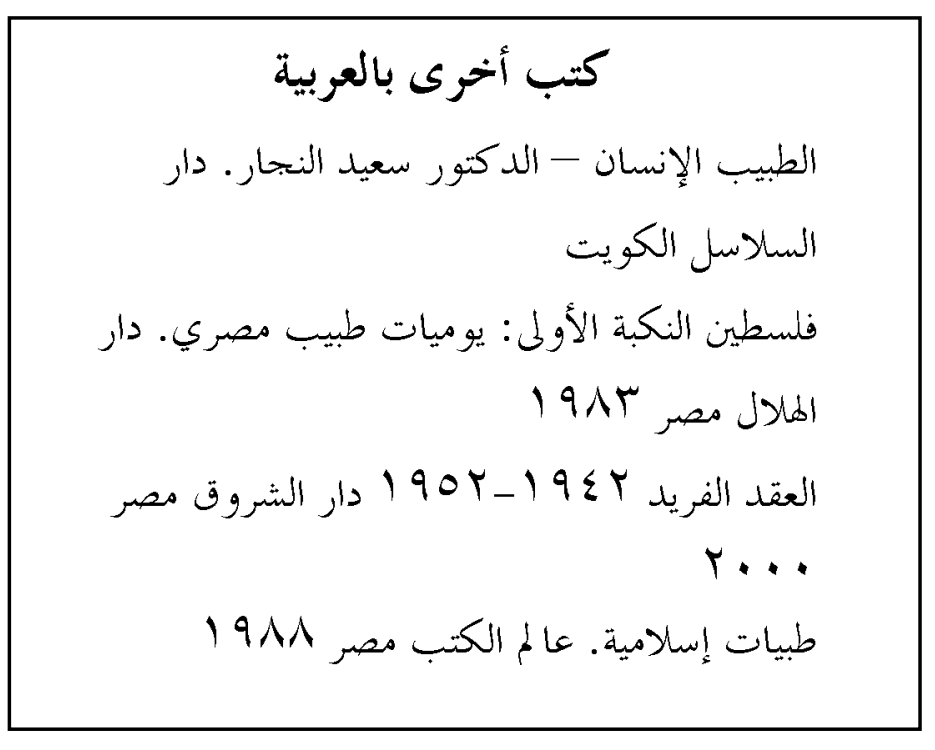


University of Southern California. He is a grandfather to Sarrah and Hassaan Shahawy.

\section{Profile submitted by}

\section{Omar Alfi, MD}

Director of Alfi Stem Cell Research and Education

Foundation, Pasadena, CA

genetics11@aol.com.

\section{References}

1. Hathout H. Islamic perspectives in obstetrics \& gynaecology. `Ālam al-kutub: Cairo; 1988.

2. Hathout H. Topics in Islamic Medicine. Islamic Organization of Islamic Medicine: Kuwait; 1984.

3. Hathout H. The Spirit of the Red Cross in the Teachings of Islam. IOMS, Kuwait.

4. Hathout H. Islamic Code of Medical Ethics. IOMS: Kuwait; 1981.

5. Hathout H. Jirāh wa afrāh. Dār al-Qalam: Kuwait; 1977.

6. Hathout H. Audible silence: thoughts and remembrances of a Muslim elder. Shorouk Bookshop: Cairo; 2006. 